\title{
Postoperative complications after liver resection in patients with focal lesions
}

\author{
Nurbek Ilyassov ${ }^{1}{ }^{2}$ \\ ${ }^{1}$ Department of General and Thoracic Surgery, \\ National Scientific Medical Center, Nur-Sultan city, \\ Republic of Kazakhstan \\ ${ }^{2}$ №2 Department of Surgical Diseases, Medical \\ University Astana, Nur-Sultan city, Republic of \\ Kazakhstan
}

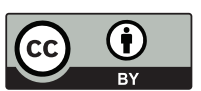

This work is licensed under a Creative Commons Attribution $\mathbf{4 . 0}$ International License

Received: 2020-02-27

Accepted: 2020-03-15

UDC: 618.1

\section{J Clin Med Kaz 2020; 1(55):32-35}

Corresponding Author: Nurbek Ilyassov, Department of General and Thoracic Surgery, National Scientific Medical Center. Address: 42, Abylai-Khan avenue, Nur-Sultan city, 010000, Republic of Kazakhstan.

Email: ylyasov@inbox.ru

\section{Abstract}

Aims: To study the main complications in the immediate postoperative period after resection of the liver of various sizes in patients with focal diseases. To conduct a comparative analysis of the frequency of complications depending on the volume of surgical intervention and the assessment of prognostic factors for the timely detection of post-resection complications.

Material and methods: A retrospective analysis was performed in 97 patients with focal liver diseases who were undergoing surgical treatment from 2010 to 2016. Of 97 patients undergoing liver resection, 26 noted various complications in the immediate postoperative period.

Results: The most common complication is suppuration of the surgical wound (37.1\%), pleural effusion (22.6\%), liver failure (19.5\%), persistent ascites $(7.2 \%)$, less common complications included biliary fistulas (2\%), thrombophlebitis $(2 \%)$ and intra-abdominal bleeding (1\%). An important point affecting the results of surgical treatment was the volume of the resected liver, respectively, and the complication rate reached in $33.3 \%-50 \%$ of cases.

Conclusion: Aconnection was found between the use of extensive liver resection, a change in the immunological status and the occurrence of various complications, despite the standard management of patients.

Key words: infections, postoperative complications, liver resection, risk factors

\section{ОШАҚТЫ ЗАҚЫМДАНУЫ БАР НАУҚАСТАРДЫН БАУЫР РЕЗЕКЦИЯСЫ ОПЕРАЦИЯСЫНАН КЕЙІНГІ АСҚЫНУЛАР Н.К. Ильясов ${ }^{1},{ }^{2}$ \\ 'Жалпы және торакальді хирургия бөлімі, Ұлттық ғылыми медициналық орталық, Нұр-Сұлтан қаласы, Қазақстан Республикасы ${ }^{2} № 2$ Хирургиялық аурулар бөлімі болезней, Астана медициналық университеті, Нұр-Сұлтан қаласы, Қазақстан Республикасы}

\section{ТҰЖЫРЫМДАМА}

Мақсаты: Фокустық аурулары бар науқастарда әр түрлі мөлшердегі бауыр резекциясынан кейінгі операциядан кейінгі кезеңде негізгі асқынуларды зерттеу. Хирургиялық араласу көлеміне және резекциядан кейінгі асқынуларды уақытында анықтау үшін болжамдық факторларды бағалауға байланысты асқынулар жиілігіне салыстырмалы талдау жүргізу.

Әдістері: 2010 жылдан 2016 жылға дейін хирургиялық емдеуден өткен бауырдың ошақты аурулары бар 97 пациентке ретроспективті талдау жасалды. Бауыр резекциясы жасалынған 97 пациенттің 26-ы операциядан кейінгі кезеңде әр түрлі асқынуларды атап өтті.

Нәтижелері: Еңжиі кездесетін асқыну - хирургиялық жараның іріңдеуі (37,1\%), плевра қуысынын сұйықтығы (22,6\%), бауыр жеткіліксіздігі (19,5\%), тұрақты асцит $(7,2 \%)$, өт жолдарының жыланкөзі (2\%) тромбофлебит (2\%) және іш ішілік қан кету (1\%). Хирургиялық емдеудің нәтижелеріне әсер ететін маңызды сәт, сәйкесінше, қалпына келтірілген бауырдың көлемі болды, ал асқыну 33,3\% - 50\% жағдайға жетті.

Қорытынды: Науқастарды стандартты басқаруға қарамастан, бауырдың кең резекциясын қолдану, иммунологиялық мәртебенің өзгеруі және әртүрлі асқынулардың арасында байланыс табылды.

Негізгі сөздер: инфекциялар, операциядан кейінгі асқынулар, бауырдың резекциясы, қауіп фракторлары

\section{ПОСЛЕОПЕРАЦИОНЫЕ ОСЛОЖНЕНИЯ ПРИ РЕЗЕКЦИИ ПЕЧЕНИ У ПАЦИЕНТОВ С ОЧАГОВЫМИ ОБРАЗОВАНИЯМИ}

Н.К. Ильясов ${ }^{1},{ }^{2}$

'Отделение общей и торакальной хирургии, Национальный научный медицинский центр, город Нур-Султан, Республика Казахстан

${ }^{2}$ Кафедра хирургических болезней №2, Медицинский университет Астана, город Нур-Султан, Республика Казахстан

\section{PЕЗЮМЕ}

Цель: Изучить основные осложнения в ближайшем послеоперационном периоде после резекции печени различного объема у пациентов с очаговыми заболеваниями. Провести сравнительный анализ частоты встречаемости осложнений в зависимости от объема оперативного вмешательства и оценку прогностических факторов для своевременного выявления пострезекционных осложнений.

Материал и методы: Проведен ретроспективный анализ у 97 пациентов с очаговыми заболеваниями печени, находившихся на оперативном лечении с 2010 по 2016 гг. Из 97 пациентов, перенесших резекцию печени, у 26 отмечены различные осложнения в ближайшем послеоперационном периоде. 
Результаты: Наиболее частым осложнением является нагноение операционной раны (37,1\%), плевральный выпот (22,6\%), печеночная недостаточность (19,5\%), стойкий асцит (7,2\%), реже отмечались желчные свищи (2\%), тромбофлебит (2\%) и внутрибрюшное кровотечение (1\%). Важным моментом, влияющим на результаты оперативного лечения, явились объём резецируемой печени, соответственно и частота осложнений достигла в 33,3\% - 50\% случаях.

Заключение: Выявлена связь между применением обширной резекции печени, изменением иммунологического статуса и возникновением различного рода осложнений, несмотря на стандартное ведение пациентов.

Ключевые слова: инфекции, послеоперационные осложнения, резекция печени, факторы риска

\section{Introduction}

The introduction of new technologies in surgical hepatology has achieved some success in treating patients with focal lesions $[1,2,3,4]$. At the same time, the high incidence of postoperative infectious complications in liver resection, where the main factor is the increase in microbial resistance to antibacterial drugs and immune imbalance, are an urgent problem requiring analysis of complications and the search for prognostic factors for their timely diagnosis.

\section{Material and methods}

The medical histories of patients with focal liver diseases were retrospectively analyzed in the period from 2010 to 2016 . The exclusion criteria from the study were: age older than 80 years or younger than 18 years, the presence of malignant neoplasms. Clinical, laboratory and instrumental examinations were carried out according to the protocol of diagnosis and treatment of this category of patients. Patients underwent liver resection depending on the extent of the lesion. All the results of the examination were recorded in medical records. Statistical processing was performed using Student T-test.

All patients were informed about the purpose of the study, informed consent was received. In order to protect patient confidentiality, all identifying information was hided (first name, last name).

\section{Results}

Of 179 patients diagnosed with liver formation, 97 (54.1\%) were subjected to resections of various scopes (Table 1). The age of patients ranged from 22 to 79 years (average 45 years). Of these patients women - 58 (59.79\%), men - $39(40.20 \%)$. Due to the severity of the pathological process (capture of more than 5 segments) or the small size of the formation - for $82(45.8 \%)$ patients another treatment method was chosen - HIFU therapy (High Intensity Focused Ultrasound).

The largest amount of liver resection was performed for echinococcosis $69(71.13 \%)$, the smallest amount for liver abscess - 3 (3.09\%).

The nature and frequency of complications after liver resection are presented in Table 2.

Table $1 \quad$ Focal liver disease

\begin{tabular}{|l|l|l|}
\hline \multirow{2}{*}{ The nature of focal lesion } & Number of patients & \\
\cline { 2 - 3 } & $\mathrm{N}$ & $\%$ \\
\hline Echinococcosis & 69 & $71,13 \%$ \\
\hline Alveococcosis & 11 & $11,34 \%$ \\
\hline Hemangioma & 9 & $9,27 \%$ \\
\hline Simple cysts & 5 & $5,15 \%$ \\
\hline Abscesses & 3 & $3,09 \%$ \\
\hline TOTAL & 97 & 100 \\
\hline
\end{tabular}

Table 2 The nature and frequency of complications after liver resection

\begin{tabular}{|c|c|c|c|c|}
\hline \multirow[t]{3}{*}{ Complication } & \multicolumn{4}{|c|}{ Frequency of complications } \\
\hline & \multicolumn{2}{|c|}{ Number of patients } & \multicolumn{2}{|c|}{ Mortality } \\
\hline & $\mathrm{n}$ & $\%$ & $\mathrm{~N}$ & $\%$ \\
\hline Pleural effusion & 22 & $22,6 \%$ & - & - \\
\hline Liver failure & 19 & $19,5 \%$ & - & - \\
\hline Ascites & 7 & $7,2 \%$ & - & - \\
\hline \multirow{3}{*}{$\begin{array}{l}\text { Free fluid in the abdominal cavity } \\
\text {-Under diaphragm } \\
\text {-Under liver } \\
\text {-Liver abscesses }\end{array}$} & 4 & $4,1 \%$ & - & - \\
\hline & 5 & $5,1 \%$ & - & - \\
\hline & - & - & - & - \\
\hline Intraabdominal bleeding & 1 & $1,0 \%$ & - & - \\
\hline Biliary fistulas & 2 & $2,0 \%$ & - & - \\
\hline Pneumonia & 3 & $3,0 \%$ & - & - \\
\hline Pulmonary embolism & - & - & - & - \\
\hline Thrombophlebitis & 2 & $2,0 \%$ & - & - \\
\hline Wound suppuration & 36 & $37,1 \%$ & - & - \\
\hline Hemorrhagic shock & - & - & - & - \\
\hline Number of complications & 91 & & & \\
\hline Number of patients with complications & 26 & $26,8 \%$ & - & - \\
\hline
\end{tabular}


The dependence of the type of surgical intervention and the frequency of complications is shown in Table 3. It is noted that the larger the volume of liver resection, the more complications develop in the postoperative period. For example, after extended right-sided hemihepatectomy and right-sided hemihepatectomy, complications were detected in $50 \%$ and $33.0 \%$ of cases, respectively. Significantly less often, they were observed after atypical bisegmentectomy (14.5\%).

Table 3 The frequency of complications depending on the type of surgical intervention

\begin{tabular}{|c|c|c|c|c|c|}
\hline \multirow[t]{3}{*}{ Type of surgery } & \multirow{3}{*}{$\begin{array}{l}\text { Number of } \\
\text { patients }\end{array}$} & & & & \\
\hline & & \multicolumn{2}{|c|}{ Complications } & \multicolumn{2}{|c|}{ Mortality } \\
\hline & & $\mathrm{N}$ & $\%$ & $\mathrm{~N}$ & $\%$ \\
\hline $\begin{array}{l}\text { Extended right-sided } \\
\text { hemihepatectomy }\end{array}$ & 4 & 2 & $50 \%$ & - & - \\
\hline $\begin{array}{l}\text { Right-sided } \\
\text { hemihepatectomy }\end{array}$ & 6 & 2 & $33,3 \%$ & - & - \\
\hline $\begin{array}{l}\text { Left-sided } \\
\text { hemihepatectomy }\end{array}$ & 1 & - & & - & - \\
\hline $\begin{array}{l}\text { Atypical resection } \\
\text { (bisegmentectomy) }\end{array}$ & 48 & 7 & $14,5 \%$ & - & - \\
\hline $\begin{array}{l}\text { Atypical resection } \\
\text { (trisegmentectomy) }\end{array}$ & 23 & 5 & $21,7 \%$ & - & - \\
\hline $\begin{array}{l}\text { Atypical resection } \\
\text { (more than } \\
\text { trisegmentectomy) }\end{array}$ & 15 & 3 & $20 \%$ & - & - \\
\hline TOTAL & 97 & 19 & $19,5 \%$ & - & - \\
\hline
\end{tabular}

\section{Discussion}

A significant factor affecting the results of the operation was the volume of liver resection. The most common complications were with extensive resections $(66 \%$ and $72.2 \%)$. The paper presents the frequency of complications of liver resection and factors affecting their occurrence.

Of 97 patients, $26(26.8 \%)$ patients had various complications in the immediate postoperative period; no fatal outcome was observed ( $0 \%$ ) (Table 2). In 26 patients, 91 complications were observed. As can be seen from the data in the table, suppuration of the postoperative wound was most often observed (37.1\%). In the second place was pleural effusion $(22.6 \%)$, in the third - hepatic cell failure (19.5\%). The least common complications were abdominal postoperative bleeding (1.0\%), suppuration of the wound (1.8\%), bile fistula $(2.0 \%)$ and thrombophlebitis of the vessels of the lower extremities $(2.0 \%)$.

Suppuration of a postoperative wound after a liver resection is the most common complication, the diagnosis of which does not present any special difficulties. It was noted in 36 patients. The frequency of infection is not uncommon for this category of patients. In all cases, the described complications were cured.

According to the literature, these complications occur in $14 \%(5-22 \%)$ of cases $[4,5,6,7]$. One of the reasons for the accumulation of fluid after resection is the presence of necrotic liver tissue, as well as the accumulation of fluid in sloping places. Abdominal ultrasound performed for 9 patients on 3-5-7 days after surgery allowed to establish the nature and dynamics of changes in the postoperative side. Computed tomography made it possible to accurately determine the localization of the pathological process. In 2 patients, hemobilomas were diagnosed, in 1 patient it was resolved after conservative therapy, and in another patient, puncture aspiration was applied.

According to the literature, pleural effusion occurs in approximately $30 \%(9 \%-73 \%)$ of cases and is recognized by most authors as the most frequent complication after liver resection $[8,9,10,11]$. In most patients, effusion in the pleural cavity are asymptomatic and are rarely eliminated by repeated pleural punctures.

Pneumonia after liver resection is a common complication in surgery, associated with a high probability of infection in a weakened body. The liver plays an immunological role, is the site of maturation and activation of various immune components, and liver resection reduces the patient's immune status. A decrease in immunity in turn increases the risks of developing infectious complications. In $3(3.0 \%)$ patients, nosocomial pneumonia was observed which responded well to antibiotic therapy.

Hepatic cell failure observed in 19 (19.5\%) patients was the most dangerous complication in the postoperative period, which was restored on 7-10 days after surgery.

In our clinic, from 2010 to 2016, not a single fatal case was registered after liver failure in the postoperative period. Literature data shows that liver failure is observed in $10 \%$ of cases $(3-75 \%)$, of which $90 \%$ is the main cause of deaths after liver resection $[5,8,12,13,14]$. Some sources say that the high regenerative ability of the liver parenchyma in many cases allows removing $80-90 \%$ of the organ without complications [15]. The mechanism of liver failure after liver resection has not been yet elucidated. According to the literature, it is known that after liver resection exceeding $75-80 \%$, liver failure occurs. The maximum resection is considered to be $75-80 \%$ [16]. The occurrence of a complication in the part of the liver remaining after resection is associated with an operative trauma, activation of Kupffer cells [17], impaired microcirculation [18], and the action of intestinal endotoxin [19]. To all this, factors such as bleeding, infection, the presence of concomitant liver disease (hepatitis, liver cirrhosis, prolonged clamping of the hepatoduodenal ligament, etc.) reduce the functional reserve of the liver and lead to disruption of regenerative processes, which contributes to the development of liver failure [14,18,19,20].

Persistent ascites was found in 7 (7.2\%) patients (with concomitant cirrhosis of the liver - 2, with extensive resections of the organ parenchyma - 5).

Portal hypertension, functional impairment of renal function and a decrease in oncotic pressure are considered to be the main mechanisms of ascites, which are associated with pathogenetic factors: a decrease in the synthesis of albumin and oncotic plasma pressure; damage to the intrahepatic lymphatic vessels, a decrease in the inactivation of antidiuretic hormone in the liver, and an increase water reabsorption in the kidneys, hypovolemia, activation of the renin-angiotensin-aldosterone system and sodium absorption [10, 13, 20, 21].

Biliary fistula, which closed independently, was observed in $2(2.0 \%)$ patients. Intraperitoneal bleeding, which required emergency relaparotomy, was observed in 1 patient. A relaparotomy was performed, the cause was bleeding from the edge of the liver resection, which required additional ligation of the bleeding vessel, and subsequently developed the syndrome of disseminated intravascular coagulation and liver failure.

According to the results of the analysis of liver resections, complications that occur depend on the volume of the resected part of the organ and the immunological status of the body. The paper presents the frequency of complications of liver resection and factors affecting their occurrence. A significant factor affecting the results of the operation was the volume of liver resection. The most common complications were with extensive resections $(66 \%$ and $72.2 \%)$. Postoperative complications developed in 2 of $4(50.0 \%)$ patients after extensive rightsided hemihepatectomy, in 2 of $6(33.3 \%)$ after right-sided hemihepatectomy, atypical resection (bisegmentectomy) - in 7 
of $48(14.5 \%)$, atypical resection (trisegmentectomy) in 5 out of $23(21.7 \%)$, atypical resection (more than 3 segmentectomy) in 3 out of $15(20.0 \%)$ patients. At the same time, in the literature on this issue opinions are mixed. Some authors reliably proved that the smaller the volume of the removed part of the liver, the less complications develop in the postoperative period, the better the survival rate of patients $[22,23]$. In other studies, there was a statistically significant absence of differences in the number of postoperative complications and mortality in patients who underwent extensive resection and removal of a small part of the liver [5].

\section{Conclusion}

The use of advanced surgical methods and various new devices, suture materials significantly improve the quality of surgical intervention on liver. Making the right decision when performing various volumes of surgery on liver, significantly affects the outcome of the operation. Preoperative predicted factors will improve the quality and outcome of surgical intervention in patients with indications for extensive liver resection, taking into account the prevention of both early and late complications.

Conflict of interest statement: None declared. Source of research support: None.

\section{References}

1. Vishnevskii VA, Nazarenko HA, Chzhao A.B et al. Extensive resections with metastatic liver damage [in Russian]. Annaly khirurgicheskoi gepatologii. 1999; 4(2):185-186.

2. Cohnert TU, Rau HG, Buttler E, et al. Preoperative assessment of hepatic resection for alignant disease. J. Surg. 1997; 21(4):396401. https://doi.org/10.1007/PL00012260

3. Fabbrucci P, Androsoni G, Falchi A. Liver resection with the water dissector: preliminary experience of 8 cases. Ann Ital Chir. 1999; 70(1):99-103.

4. Shimada M, Matsumata T, Akazawa K. et al. Estimation risk of major complications after hepatic resection. Amer. J. Surg. 1994;167(4):399-403. https://doi.org/10.1016/0002-9610(94)90124-4

5. Kim YJ, Nakashima K, Tada I, et al. Prolonged normothermic ischaemia of human cirrhotic liver during hepatectomy: a preliminary report. Br. J. Surg. 1993; 80:1566-1570. https://doi.org/10.1002/bjs.1800801225

6. Pinkerton JA, Sawyers JL, Foster JH. A study of the postoperative course after hepatic lobectomy. Ann. Surg. 1971; 173(5):800811. https://doi.org/10.1097/00000658-197105000-00020

7. Segawa T, Tsuchiya R, Furui J. et al. Operative results in 143 patients with hepatocellular carcinoma. World J. Surg. 1993; 17(5):663-667. https://doi.org/10.1007/BF01659138

8. Capussotti L, Borgonovo G, Bouzari H, et al. Result of major hepatectomy for large primary liver cancer in patients with cirrhosis. Brit. J. Surg. 1994; 81(3):427-431. https://doi.org/10.1002/bjs.1800810335

9. $\mathrm{Hu} \mathrm{RH}, \mathrm{Lee} \mathrm{PH}$, Yu SC. et al. Surgical resection for hepatocellular carcinoma: prognosis and analisis of risk factors. Surgery. 1996; 120(1):23-29. https://doi.org/10.1016/S0039-6060(96)80236-4

10. Matsumata T, Kanematsu T, Okudarira Y. et al. Postoperative mechanical ventilation preventing the occurrence of pleural effusion after hepatectomy. Surgery. 1987; 102(3)493-497.

11. Uetsuji S, Komada Y, Kwon AH. et al. Prevention of pleural effusion after hepatectomy using fibrin sealant. Int. Surg. 1994; 79(2):135-137.

12. Nagasue N, Yukaya H, Ogawa Y, Sasaki Y. et al. Clinical experience with 118 hepatic resections for hepatocellular carcinoma. Surgery. 1986; 99(6):694-701.

13. Pirte J, Houssin D, Kracht M. Resection of hepatocellular carcinomas. Analysis of prognostic factors of a multicenter series of 153 patients. Gastroenterol. Clin. Biol. 1993;17(3):200-206.

14. Yamanaka N, Okamoto E. et al. A prediction scoring system to select the surgical treatment of liver cancer. Further refinement based 10 years of use. Ann. Surg. 1994; 219(4)342-346. https://doi.org/10.1097/00000658-199404000-00003

15. Rabes HM, Tuczek HV, Wirshing R. Liver regeneration after experimental injury. New York: Grune\&Stratton. $1979 ; 35-52$.

16. Roger V, Balladur P, Honiger J, Delelo R, Baudri-rnont M. et al. A good model of acute hepatic failure: $95 \%$ hepatectomy. Treatment by transplantation of hepatocytes. Chirurgie. 1996; 121(6)470-473.

17. Gertsch P, Stipa F, Ho J, Yuen ST, Luk I, et al. Changes in hepatic portal resistance and liver morphology during regeneration: in vitro study in rats. Eur. J. Surg. 1907; 163(4):297-304.

18. Panis Y, McMulIan DM, Emond JC. Progressive necrosis after hepatectomy and the pathophysiology of liver failure after massive resection. Surgery. 1997; 121(2):142-149. https://doi.org/10.1016/S0039-6060(97)90283-X

19. Van-Leeuwen PA, Hong RW, Rounds JD. et al. Hepatic failure and coma after liver resection is reversed by manipulation of gut contents: the role of endotoxin. Surgery. 1991; 110(2):169-175. https://doi.org/10.1016/0261-5614(91)90171-8

20. Klein AS, Smith GW. Diagnostic operations of the liver and techniques of hepatic resection. In: Shacklefords Surgery of the Alimentary Tract. Saunders. 1996; 578-599.

21. Williams R. Treatment of acute liver failure. In: Arroyo V, Bosch J, Rodes J. Treatments in Hepatolo-gy. Barcelone: Masson. $1995 ; 365-374$.

22. Patyutko YuI, Panakhov DM. Prognosis factors for primary malignant tumors of the liver [in Russian]. Annaly khirurgicheskoi gepatologii. 1997; 2:25-31.

23. Wu CC, Ho WL. Yeh DS. et al. Hepatic resection of hepatocellular carcinoma in cirrhotic livers: is it unjustified in impaired liver function? Surgery. 1996; 120(1):34-39. https://doi.org/10.1016/S0039-6060(96)80238-8

How to cite this article: Nurbek Ilyassov. Postoperative complications after liver resection in patients with focal lesions. J Clin Med Kaz. 2020; 1(55):32-35 